\title{
ETNOZOOLOGI: STUDI KEARIFAN LOKAL MASYARAKAT ADAT KAMPUNG NAGA TASIKMALAYA
}

\author{
Yustika Ayu Sekartaji, Diana Hernawati, Vita Meylani \\ Universitas Siliwangi \\ yustikaayu07@gmail.com
}

\section{Naskah diterima tanggal 14 Juni 2021, di setujui tanggal 25 Oktober, diterbitkan tanggal 30 November 2021}

\begin{abstract}
Ethnozoological study is a study that examines the relationship between humans and animals in traditional studies. People's knowledge in relation to these animals has been passed down from generation to generation to become local wisdom. This ethnozoology includes the matter of raising animals, managing animals for medicine, food and customary and ritual activities, as well as the reciprocal relationship between humans and surrounding animals. The people of Kampung Naga are indigenous people located in Tasikmalaya who still adhere to the local wisdom they have today. Due to the absence of a study on ethnozoological studies in the Kampung Naga community, research was carried out on animal maintenance and control of rice pests which were included in the study of ethnozoological studies. The data collection techniques in this study were interview techniques and documentation with qualitative research methods. The results of the study found that the people of Kampung Naga have local wisdom regarding the control of agricultural pests, the main pests are brown planthopper, walang sangit, rats and birds as well as animal maintenance including chickens, goats, fish, guinea pigs and rabbits. This study aims to describe the study of ethnozoological studies of the people of Kampung Naga, Neglasari Village, Salawu District, Tasikmalaya Regency as a source of learning biology in the form of a booklet.
\end{abstract}

Keywords: Kampung Naga, Ethnozoology, Animals, Rice Pests, Raising of Animals

\section{PENDAHULUAN}

Etnozoologi merupakan studi yang mengkaji mengenai interaksi manusia dengan hewan. Iskandar (2018) studi etnozoologi mengkaji mengenai persepsi budaya dan sistem klasifikasi zoologi, mitos kepercayaan penduduk, aspek biologi dan budaya penggunaan binatang oleh manusia, metoda pemanfaatan binatang untuk pangan, obat tradisional, bahan ritual, kosmetik, pemeliharaan binatang oleh penduduk secara lekat budaya dan pengelolaan dan konservasi binatang. Penelitian mengenai studi ini tidak sebanyak studi etnobotani, karena masyarakat pada umumnya lebih memilih menggunakan tumbuhan daripada hewan untuk keperluan sehari-hari, namun tidak menutup kemungkinan masih adanya kelompok masyarakat yang masih menggunakan hewan untuk kegiatan seharihari mereka, masyarakat tersebut merupakan masyarakat tradisional.

Masyarakat tradisional merupakan masyarakat yang masih mempertahankan kearifan lokal mengenai adat istiadat yang dipercaya dan dijaga hingga sekarang. Kearifan lokal merupakan pengetahuan lokal yang digunakan oleh masyarakat untuk bertahan hidup dalam suatu lingkungan yang menyatu dengan sistem kepercayaan, norma, budaya dan diekspresikan dalam tradisi dan mitos yang dianut dalam jangka waktu yang lama (Sufia, Sumarmi, \& Amirudin, 2016). Tradisi dan mitos yang berlaku mengatur dalam berbagai aspek kepercayaan dalam segala hal, termasuk mengenai pengelolaan () 2021 Florea: Jurnal Biologi dan Pembelajarannya | 103 
hewan dalam sehari-hari. Hal ini menjadi sebuah aturan yang selalu dipertahankan oleh berbagai masyarakat tradisional yang terdapat di setiap wilayah Indonesia. Kearifan lokal dapat diartikan sebagai berbagai bentuk pengetahuan baik nilai, norma, maupun aturan khusus di sini mengandung pengertian sebagai nilai-nilai luhur yang berlaku dalam tata kehidupan masyarakat, antara lain untuk melindungi dan mengelola lingkungan hidup secara lestari bagi kehidupan masyarakat ada didalamnya serta tetap menjaga dengan baik (Unayah dan Sebarisman, 2016). Indonesia sendiri memiliki banyak masyarakat adat yang tersebar berbagai daerah, salah satunya adalah masyarakat Kampung Adat Naga yang terletak di Tasikmalya Provinsi Jawa Barat. Masyarakat Kampung Naga memiliki lahan untuk bertani padi dan memiliki pengelolaan sendiri mengenai hama dalam tradisi mereka. Selain bertani mereka pun memiliki kearifan lokal dalam pemeliharaan hewan ternak. Hal ini sejalan dengan kajian etnozoologi yaitu pengelolaan hewan berupa pengelolaan hewan berupa pengelolaan hama pada tanaman padi, serta pemeliharaan binatang oleh penduduk berupa kearifan lokal dalam pemeliharaan hewan ternak. Kajian mengenai studi etnozoologi di Kampung Naga akan sangat menarik untuk dikaji lebih dalam sehingga tujuan dari penelitian ini yaitu untuk mendeskripsikan mengenai kajian Etnozoologi Masyarakat Kampung Naga Desa Neglasari Kecamatan Salawu Kabupaten Tasikmalaya.

\section{METODE PENELITIAN}

Penelitian ini dilaksanankan di Kampung Naga Desa Neglasari Kecamatan Salawu Kabupaten Tasikmalaya Provinsi Jawa Barat. Penelitian ini dilakukan pada bulan Januari dan dilakukan selama satu bulan, menyesuaikan dengan waktu kesediaan narasumber untuk diwawancara. Salawu Kabupaten Tasikmalaya Provinsi Jawa Barat.

Penelitian ini menggunakan penelitian kualitatif dengan pendekatan etnografis. Etnografis ini digunakan untuk meneliti perilaku-perilaku manusia berkaitan dengan perkembangan teknologi komunikasi dalam seting sosial dan budaya tertentu. Teknik pengumpulan data dengan menggunakan observasi partisipatif dan wawancara semi terstruktur kepada tourguide dan masyarakat Kampung Naga. serta literatur dari berbagai sumber.

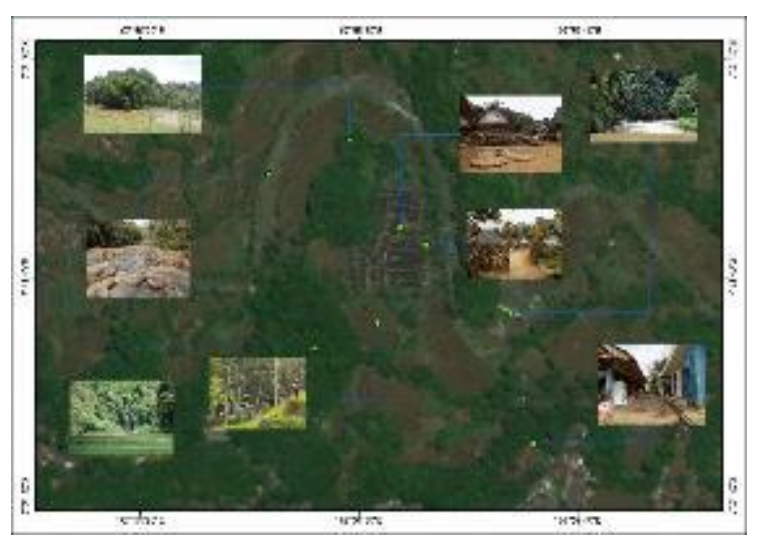

Gambar 1. Peta wilayah kampung naga

\section{HASIL DAN PEMBAHASAN}

\section{Sejarah Kampung Naga.}

Berdasarkan wawancara yang dilakukan kepada tour guide, sejarah
Kampung Naga tidak dapat dijelaskan secara jelas darimana asal usul adanya masyarakat Kampung Naga, sebab buku yang menceritakan asal usul Kampung 
Naga yang dituliskan dalam Bahasa Sansakerta pada tahun 1956, buku tersebut ikut terbakar beserta pusaka-pusakanya oleh gerombolan DI/TII pimpinan Kartosuwiryo hanya sebagian kecil benda pusaka yang dapat terselamatkan. Kampung Naga sendiri berasal dari bahasa sunda dari kata nagawir/tebing, karena Kampung Naga berada di bawah dan dikelilingi oleh tebing-tebing. Kampung Naga sendiri memiliki sebutan untuk masyarakat keturunan asli Kampung Naga yaitu Sanaga, baik itu yang tinggal di luar kampung atau yang tinggal di dalam kampung. Masyarakat Kampung Naga memiliki keyakinan bahwa asal usul Kampung Naga berasal dari sembah dalem Eyang Singaparna, yang dimakamkan sisi sebelah barat Kampung Naga, yang disebut dengan hutan keramat. Masyarakat Kampung Naga sendiri percaya bahwa sembah dalem Eyang Singaparna yang menjadi panutan seluruh tatanan kehidupan tradisi adat serta hukum adat yang berlaku sampai sekarang. Masyarakat Kampung Naga memegang teguh aturan-aturan. Di Kampung Naga tidak memiliki banyak larangan tetapi jika hukum adat sudah ditetapkan itu sudah jadi ketentuan. Kampung Naga yang berasal dari kata Nagawir memiliki arti bahwa Kampung Naga dikelilingi oleh lembah dan bersampingan dengan sungai Ciwulan.

Perkampungan adat naga memiliki 1,5 Ha. Bagian timur dibatasi oleh sungai Ciwulan, dan memiliki batas alam berupa hutan larangan, bagian barat dibatasi bukit kecil dan batas alamnya merupakan hutan keramat, serta utara dan selatan dibatasi oleh persawahan. Masyarakat Sanaga bermata pencahariannya sebagai petani padi serta beberapa diantaranya mempunyai pekerjaan sampingan di luar Kampung Naga, selain bertani masyarakatnya pun di sela-sela kegiatannya membuat kerajinan dari bambu.

\section{Sistem Pengelolaan Padi Kampung Naga}

Masyarakat Kampung Naga memiliki pekerjaan pokok sebagai petani, sebagian lainnya merupakan milik pribadi dan sebagian warganya yang tidak memiliki lahan sebagai buruh petani. Sumarlina, Darsa, \& Permana, 2019 menjelaskan sistem penanaman pada dasarnya sisitem bercocok tanaman padi di Kampung Naga sama dengan petani lain di Jawa Barat, namun terdapat beberapa perbedaan dari kebiasaan maupun tatacara. Dalam sistem penanaman hingga panen, masyarakat Kampung Naga menggunakan sistem Jan-Li atau Januari-Juli, dimana proses penanaman dilakukan serempak pada bulan januari dan bulan juli, sehingga dalam prosesnya dilakukan 2kali setahunnya.

Kampung Naga sama halnya dengan kampung adat lain memiliki kalender yang mnegatur dalam sistem pengelolaan padi secara keseluruhan. Menurut (Sidik Permana, Johan Iskandar, 2018). Tahapan pengelolaan padi mulai dari pemilihan benih hingga penyimpanan padi memperhatikan sistem kalender tradisional yang disebut dengan pranata mangsa, berdasarkan pranata mangsa sebagai pedoman dalam bertani padi dan upacara pertanian yang dipengaruhi oleh 2 musim yaitu, musim hujan dan musim kemara 


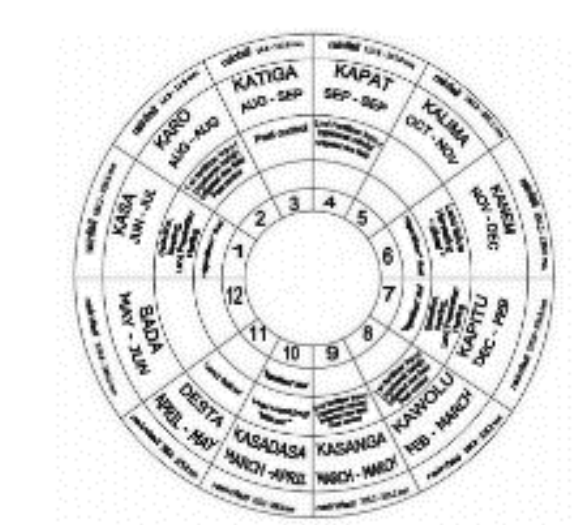

Gambar 2. Kalender pranata mangsa (sidik et al, 2018)

Kampung Naga sendiri memiliki banyak varietas padi yang ditanam, namun dapat dibedakan berdasarkan jenis padi yaitu pare segon dan pare ageung/ranggeuyan. Pare segon merupakan padi jenis unggul yang ditanam pada waktu sebentar yaitu pada bulan Januari, Februari dan Maret. Pada bulan Maret ini padi siap untuk dipanen, sedangkan pare ageung merupakan padi lokal yang waktu panen yang cukup lama yaitu meliputi bulan Juni, Juli, Agustus, Septembe, Oktober dan November, pada bulan November padi siap untuk dipanen, padi lokal pun memiliki perbedaan dari bulir padi unggul, padi lokal yang terdapat di Kampung Naga memiliki bulir yang cukup besar dari padi pada uumnya. Pada bulan April, Mei dan Desember adalah wkatu ladang di istirahatkan. Dalam sistem penanaman tersebut masyarakat Kampung Naga menggunakan istilah Tahun Ageung dan Tahun Alit berdasarkan waktu lama atau sebentarnya penanaman padi. Penanaman tersebut dilakukan serempak dalam satu bulan oleh masyarakat Kampung Naga, jadi dalam panen pun dilakukan serempak dalam satu bulan yang sama. Hal tersebut sudah menjadi aturan yang tidak boleh dilanggar oleh masyarakat, jika dilanggar akan terjadi kegagalan panen ataupun hasil panen yang habis oleh hama. Selama proses penanaman hingga panen dilakukan pengecekan ke ladang untuk memastikan ada tidaknya hama.

\section{Pengelolaan Hama Oleh Masyarakat Kampung Naga}

Hama pada tanaman padi merupakan salah satu faktor yang menyebabkan kegagalan panen padi di Indonesia, hamahama padi ini menyerang berbagai jenis bagian pada tanaman padi seperti daun, biji, batang. Hama padi merupakan salah satu faktor dari kegagalan panen yang cukup tinggi. Berdasarkan wawancara yang dilakukan kepada masyarakat serta tour guide disebutkan bahwa masyarakat Kampung Naga tidak pernah mengalami kegagalan panen yang sangat banyak seperti di luar daerah kampung adat. Namun tidak dipungkiri jika memang dalam satu petak sawah hanya sedikit saja yang gagal atau tidak bisa dipanen akibat terkena hama, hal ini dikarenakan terdapatnya pengontrolan sawah oleh masyarakat untuk melihat adanya tidaknya hama. Selain pengontrolan tersebut, masyarakat Kampung Naga melakukan penanaman padi secara serentak, selain dari pengontrolan ke sawah serta sistem tanam yang secara serentak tersebut dengan adanya perlakuan berupa ladang yang diistirahatkan ini memberikan sebagian hewan sekitar lingkungan untuk memakan sisa hasil padi. terdapat beberapa hama padi yang menyerang di Kampung Naga yaitu walangsangit, wereng coklat, burung bondol atau burung pipit, dan tikus. hama hama tersebut memiliki cara pengendaliannya tersendiri dan sebagian masyarakat Kampung Naga masih 
menggunakan bahan alami serta sistem penanaman yang serentak untuk menghindari hama tersebut, selain bahan pestisida yang alami serta sistem penanaman yang serentak, pengistirahatan lahan yang dilakukan oleh masyarakat Kampung Naga berdampak kepada hewan hewan sekitar lahan seperti tikus yang menjadi salah satu hama. Dampak tersebut terlihat dari tingkah polah tikus yang hanya datang pada saat ladang di istirahatkan dan memakan padi yang sudah tidak dipanen atau di Kampung Naga disebut dengan turiang.

Masyarakat Kampung Naga yang memiliki perkampungan serta hidup berdampingan dengan alam sadar bahwa setiap makhluk hidup memiliki peranannya masing masing di alam, jika dihilangkan secara besar besaran atau dibasmi dengan besar besaran keseimbangan alam akan terganggu yang akhirnya akan berimbas juga kepada masyarakat ataupun manusia yang berdampingan dengan alam. Masyarakat Kampung Naga mengetahui bahwa hewan-hewan tersebut hanya mencari makan tanpa tau bagaimana menghasilkan makanan tersebut, sehingga sudah seharusnya sebagai manusia maupun masyarakat saling berbagi terhadap makhluk hidup yang lain.

\section{Konsep Pemukiman Kampung Naga}

Pemukiman Kampung Naga sudah disinggung sebelumnya bahwa Kampung Naga merupakan kampung yang dikelilingi oleh lereng yang berpotensi longsor, namun berdasarkan wawancara yang dilakukan Kampung Naga tidak pernah mengalami longsor padahal posisi atau letak Kampung Naga tepat di bawah tebing. Kampung Naga menggunakan konsep pemukiman luhur handap dnegan sistem terasering/berundak-undak (Wiradimadja, 2018).

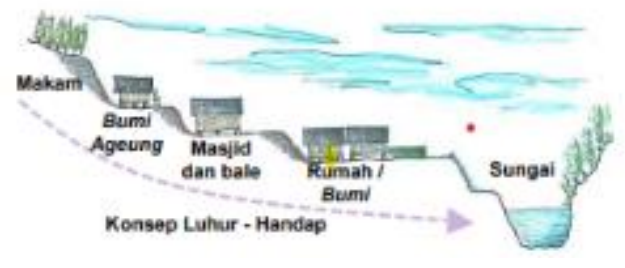

Gambar 3. Konsep luhur handap (Khairunnisa, 2014)

Berdasarkan gambar tersebut makam berada paling atas dimana makam terletak di hutan keramat yang sangat dijaga oleh masyarakat setempat. Hutan tersebut hanya boleh dimasuki hanya saat sedang ada upacara dan tidak semua warga boleh memasuki hutan keramat tersebut. Wilayah Kampung Naga ini dibagi menjadi 3 bagian yaitu wilayah suci, wilayah bersih (pemukiman) dan wilayah kotor. Wilayah suci merupakan wilayah yang dikeramatkan/disakralkan, wilayah bersih merupakan wilayah pemukiman warga Kampung Naga , sedangkan wilayah kotor adalah wilayah yang dimanfaatkan oleh warga kampung untuk menempatkan kandang ternak dan mengurai limbah rumah tangga termasuk wc ataupun kamar mandi terletak di wilayah kotor, setiap wilayah tersebut dibatasi oleh pagar bambu. Aturan mengenai tata kelola perkampungan masyarakat masih sangat terikat dengan aturan adat, rumah-rumah yang dimiliki oleh masyarakat kampung adat perlu mempertimbangkan dari segi lingkungan alam serta lingkungan sosial antar sesama masyarakat. Kampung Naga dapat ditambah namun perlu memperhatikan lahan, Kampung Naga sendiri memiliki lahan 1,5 ha meliputi imah (rumah-rumah), masjid, bale patemoan (tempat pertemuan), bumi ageung, dan bangunan leuit. Luas lahan tersebut tidak boleh ditambah lagi. Bangunan rumah masyarakat Kampung Naga diadaptasi dari perumahan sunda dahulu dimana terdapat 
kepala (para/langit-langit), badan (palupuh/lantai), kaki (kolong rumah). Kampung Naga dibangun secara panggung pada dasarnya tempat tinggal manusia yang masih hidup bukan di dunia bawah (tanah) dan juga bukan di dunia atas (langit), sehingga rumah sebagai tempat tinggal mereka harus berada di antara keduanya yaitu di dunia tengah (Hermawan, 2014). Berdasarkan wawancara yang dilakukan kepada warga serta tour guide menjelaskan bahwa bagian lantai untuk aktifitas pemilik rumah dan kolong rumah menjadi tempat pembuangan limbah memasak seperti abu, ataupun bahan organik lainnya sisa-sisa makanan, masyarakat Kampung Naga pun menggunakan kolong rumah untuk memelihara ayam hal ini menjadi kearifan lokal masyarakat Kampung Naga.

\section{Kearifan lokal masyarakat} Kampung Naga dalam pemeliharaan hewan.

Masyarakat Kampung Naga memiliki batas-batas wilayah dalam lingkungan, seperti yang sudah dijelaskan sebelumnya bahwa Kampung Naga memiliki 3 batas yaitu batas suci yaitu makam leluhur, batas perkampungan yaitu rumah rumah penduduk serta bangunan suci dan batas kotor yaitu wc, kolam dan kandang.

Pemeliharaan hewan ternak tersebut disesuaikan dengan kondisi geografi masyarakat Kampung Naga, hewan-hewan yang berukuran besar seperti sapi, kerbau ataupun hewan yang seukuran ataupun di atasnya tidak memungkinkan untuk dipelihara karena perlu menuruni dan juga menaiki anak tangga. Sehingga masyarakat Kampung Naga perlu memilah dan memilih hewan ternak apa saja yang mampu dipelihara di lingkungan Kampung Naga. Hewan-hewan kecil seperti ayam, marmut dan kelinci dipelihara di lingkungan pemukiman kampung naga. kandang ayam sendiri berada di kolong rumah yang berfungsi untuk memelihara rumah dari serangan rayap yang memakan bahan bangunan yang digunakan oleh masyarakat.

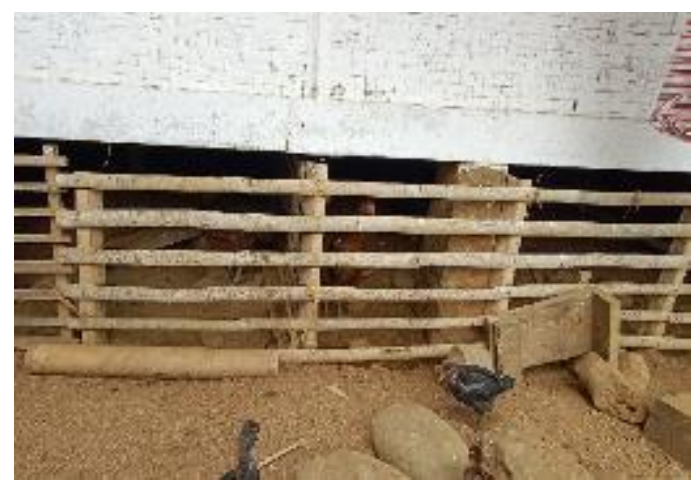

Gambar 4. Kandang ayam

Sedangkan kelinci dan marmut dipelihara di samping rumah. Berdasarkan penelitian Badan Penelitian Ternak, Urine Kotoran kelinci memiliki kandungan unsur
$\mathrm{N} 2,72 \%, \mathrm{P} 1,1 \%, \mathrm{~K} 0,5 \%$ (Nurrohman, Suryanto, \& Puji, 2014). Kotoran kelinci sendiri memiliki kandungan unsur $\mathrm{N}$ yang cukup tinggi untuk tanaman. 

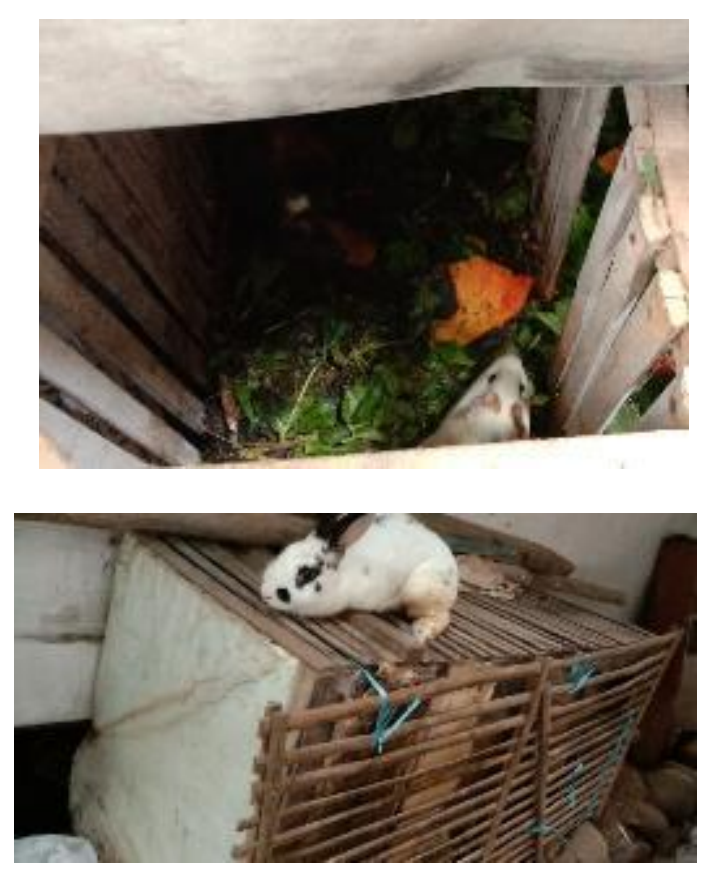

Gambar 5. Marmut dan kelinci

Hewan peliharaan tersebut hewan yang berukuran kecil, terdapat merupakan kepemilikan secara pribadi bukan kepemilikan bersama. Selain hewan pemeliharaan kambing dan ikan.

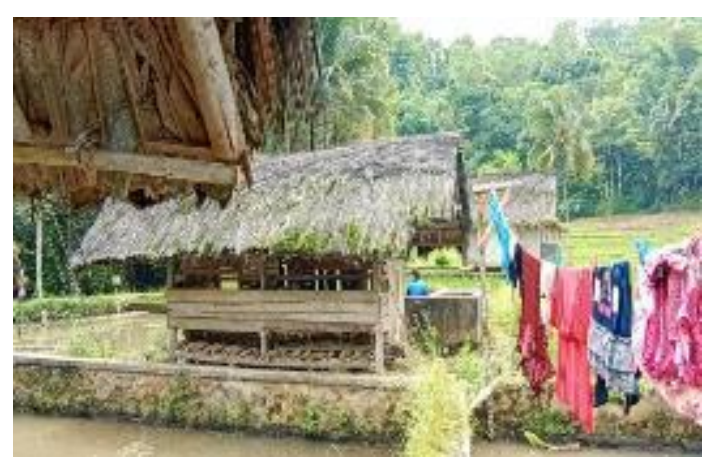

Gambar 6. Kandang kambing

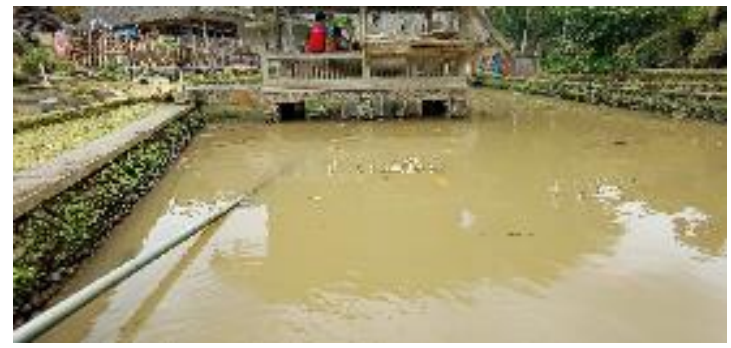

Gambar 7. Kolam ikan

Letak kandang kambing dan kolam ikan tersebut terletak di luar wilayah kampung. Hanya beberapa saja yang memelihara kambing dan pada waktu waktu tertentu saja seperti saat akan melaksanakan kurban ataupun acara cara 
tertentu, karena dalam pemeliharaan kambing masyarakat Kampung Naga kesulitan dalam akses jual beli, sehingga kambing dipelihara tidak untuk dijual kembali.

Masyarakat Kampung Naga menggunakan kotoran kambing untuk pertanian. Surya (Trivana et al 2017) menjelaskan kotoran kambing dapat dijadikan sebagai bahan organik pada pembuatan pupuk kandang karena kandungan unsur hara yang relatif tinggi. Sedangkan kolam ikan digunakan oleh masyarakat Kampung Naga untuk memakan jentik nyamuk, berdasarkan wawancara, masyarakat Kampung Naga yang mengalami kasus DBD jumlahnya kecil dibanding di luar Kampung Naga, meskipun belum adanya penelitian lebih lanjut terhadap kasus DBD ini.

\section{SIMPULAN}

Berdasarkan hasil penelitian yang dilakukan dapat disimpulkan bahwa Kampung Naga merupakan kampung adat yang terletak di Tasikmalaya, kampung ini memiliki kearifan lokal serta adat istiadat yang masih dijaga hingga saat ini. Adat istiadat tersebut dijaga dan dilestarikan oleh masyarakat, adat istiadat dan kearifan lokal tersebut salah satunya meliputi pengelolaan pertanian padi dan kearifan lokal dalam pemeliharaan hewan ternak. Kearifan lokal dalam pertanian padi tersebut meliputi penanaman hingga pengontrolan dalam penanggulangan hama.

Masyarakat Kampung Naga tidak pernah mengalami kegagalan panen yang cukup parah karena memiliki pengelolaan dan pengontrolan hama yang cukup efektif. Hama-hama tersebut meliputi walangsangit, wereng coklat, burung serta tikus. meskipun memiliki hama yang sama dengan pertanian padi diluar wilayah Kampung Naga, namun memiliki pengontrolan hama yang berbeda dan serta penanggulangan hama yang masih menggunakan cara-cara alami dan tradisional.selain pertanian padi masyarakat pun memiliki kearifan lokal dalam peternakan. Kearifan lokal tersebut diterapkan dengan menggunakan batas kampung untuk memisahkan kandang atau pun kolam.

Pemilihan ukuran hewan yang akan dipelihara oleh masyarakat perlu mempertimbangkan jarak serta kesanggupan masyarakat, karena hewan hewan besar seperti sapi, kerbau dan hewan seukurannya perlu menuruni anak tangga berjarak $600 \mathrm{~m}$. hal itu menyulitkan masyarakat untuk jual-beli masyarakat. Sedangkan hewan hewan kecil seperti ayam, kelinci maupun marmut memiliki kandang di dalam wilayah perkampungan, sedangkan kandang kambing dan kolam ikan berada di wilayah kotor bersama dengan kamar mandi dan wc.

Disarankan perlu adanya kajian lebih mendalam mengenai pertanian khususnya dalam pengetahuan masyarakat dalam kemunculan hama hama dalam bulan bulan tertentu yang dilakukan dengan waktu yang cukup lama agar didapatkan hasil yang maksimal serta diperlukan penelitian lebih lanjut mengenai etnozoologi di lingkungan masyarakat Kampung Naga selain pengontrolan hama serta pemeliharaan hewan ternak.

\section{DAFTAR PUSTAKA}

Hermawan, I. (2014). Bangunan Tradisional Kampung Naga: Bentuk Kearifan. Sosio Didaktika. https://doi.org/10.15408/sd.v1i2.1256

Iskandar, J. (2018). Etnobiologi,Etnoekologi Dan Pembangunan Berkelanjutan. Yogyakarta. Plantaxia

Khairunnisa, M. (2014). Kosmologi Ruang Adat Sebagai Identitas Pemukiman Kampung Naga, Tasikmalaya - Jawa Barat. Teknik, 35(1), 49-55. https://doi.org/10.14710/teknik.v35i1. 7040

Nurrohman, M., Suryanto, A., \& Puji, K. (2014). Penggunaan Fermentasi Ekstra Paitan (Tithonia diversifolia L.) dan 
Kotoran Kelinci Cair Sebagai Sumber Hara pada Budidaya Sawi (Brassica juncea L.) Secara Rakit Apung. Produksi Tanaman, 2(8), 650. Retrieved from http://protan.studentjournal.ub.ac.id Permana, S. (2015).Kampung Naga : Pengetahuan Ekologi Tradisional dan Pelestarian Keanekaragaman Hayati Tumbuhan.Yogyakarta. Plantaxia

Sidik Permana, Johan Iskandar, P. (2018). local knowledge on rice variations (landraces) of the Naga Comuniti, West Java, Indonesia. Asian Journal of Ethnobiology, 1(1), 224-234. https://doi.org/10.13057/asianjethnobi $\mathrm{ol} / \mathrm{y} 010101$

Sufia, R., Sumarmi, \& Amirudin, A. (2016). Kearifan Lokal Dalam Melestarikan Lingkungan Hidup (Studi Kasus Masyarakat Adat Desa Kemiren Kecamatan Glagah Kabu. Jurnal Pendidikan: Teori, Penelitian, Dan Pengembangan, 1(4), 726-731. Retrieved from http://journal.um.ac.id/index.php/jptpp /article/view/6234

Sumarlina, E. S. N., Darsa, U. A., \& Permana, R. S. M. (2019). Pemuliaan Pangan Berbasis Naskah Mantra Pertanian Dalam Kaitannya Dengan Tradisi Masyarakat Kampung Naga Dan Baduy. Jumantara: Jurnal Manuskrip Nusantara, 9(2), 69. https://doi.org/10.37014/jumantara.v9i 2.244

Trivana, L., Yudha Pradhana, A., \& Pahala Manambangtua, A. (2017). Optimalisasi Waktu Pengomposan Pupuk Kandang Dari Kotoran Kambing Dan Debu Sabut Kelapa Dengan Bioaktivator Em4. Jurnal Sains \&Teknologi Lingkungan, 9(1), $16-24$. https://doi.org/10.20885/jstl.vol9.iss1. art2

Unayah, N., \& Sabarisman, M. (2016).Idenstitas Kearifan Lokal Dalam Pemberdayakan Komunitas Adat Terpencil.Sosio Informa, 2(1).

Wiradimadja, A. (2018). Nilai-Nilai Karakter Sunda Wiwitan Kampung Naga sebagai Bahan Pembelajaran Ilmu Pengetahuan Sosial. Jurnal Pendidikan Sejarah Indonesia, 1(1), 103-116. https://doi.org/10.17977/um033v1i 12018103 